\title{
Impact of the Basel III bank regulation on US agricultural lending
}

\author{
Kevin Nooree Kim and Ani L. Katchova \\ Department of Agricultural, Environmental and Development Economics, \\ Ohio State University, Columbus, Ohio, USA
}

\begin{abstract}
Purpose - Following the recent global financial crisis, US regulatory agencies issued laws to implement the Basel III accords to ensure the resiliency of the US banking sector. Theories predict that enhanced regulations may alter credit issuance of the regulated banks due to increased capital requirements, but the direction of changes might not be straightforward especially with respect to the agricultural loans. A decrease in credit availability from banks might pose a serious problem for farmers who rely on bank credit especially during economic recessions. The paper aims to discuss these issues.
\end{abstract}

Design/methodology/approach - In this study, the impact of Basel III regulatory framework implementation on agricultural lending in the USA is examined. Using panel data of FDIC-insured banks from 2008 to 2017, the agricultural loan volume and growth rates are examined for agricultural banks and all US banks.

Findings - The results show that agricultural loan growth rates have slowed down, but the amount of agricultural loan volume issuance still remained positive. More detailed examination finds that regulated agricultural banks have decreased both the agricultural loan volume and their loan exposure to the agricultural sector, showing a possible sign of credit crunch.

Originality/value - This study examines whether the implementation of the Basel III regulation has resulted in changes in agricultural loan issuance by US banks as predicted by the lending channel theory.

Keywords Bank lending, Capital requirements, Agricultural bank, Basel accords, Farm credit

Paper type Research paper

\section{Introduction}

The financial crisis of 2007-2008 triggered significant regulatory changes for lending institutions around the world. Defaults on previously issued loans resulted in large bank failures as well as in regional bank failures in Europe and the USA. In the midst of the financial crisis, policymakers and bank regulators found it necessary to strengthen global banking regulation standards that would require banks to hold more capital to prevent spillover to the rest of the economy. In 2010, the Basel Committee on Banking Regulation and Supervision (BCBS) outlined the Basel III framework, a regulatory framework targeting the financial sector. US federal agencies - the Federal Reserve, FDIC and Office of Comptroller of Currency - issued a series of strict rules to implement Basel III requirements as well as other requirements under the Dodd-Frank Act of 2010. The main purpose of the Basel III regulation was to introduce a more prudent methodology for calculating required capital that would enable banks to withstand losses during economic recessions (Getter, 2014; Roulet, 2018). The new regulation required banks to re-calculate the risk weights of their assets, increase their capital ratio, leverage ratio, and liquidity coverage ratio, and secure conservation buffers. In this study, the impact of the new Basel III regulation on the agricultural lending practices of US banks is examined.

JEL Classification - G21, G28, Q14

(C) Kevin Nooree Kim and Ani L. Katchova. Published by Emerald Publishing Limited. This article is published under the Creative Commons Attribution (CC BY 4.0) licence. Anyone may reproduce, distribute, translate and create derivative works of this article (for both commercial and non-commercial purposes), subject to full attribution to the original publication and authors. The full terms of this licence may be seen at http://creativecommons.org/licences/by/4.0/legalcode

Basel III bank regulation on US agricultural lending

Received 25 November 2019 Revised 29 November 2019 Accepted 2 December 2019 
AFR

80,3

322

The bank lending channel theory suggests that bank loan portfolios and the supply of loans from banks are expected to adjust in accordance with changes in regulatory policy. Even though the new Basel III regulations aimed to strengthen the financial health of banks and prevent them from taking excessive risk including non-traditional banking activities such as securitization, there has been a growing concern over the possibility that these stringent rules hamper the credit issuance from banking institutions, even for traditional loans such as commercial loans and agricultural loans (Repullo and Saurina, 2011; Mustilli et al., 2017; Roulet, 2018). A change in the minimum capital requirement and implementation of risk-based capital, which are part of the Basel III regulation, are theorized to affect bank credit supply because violating the requirement triggers both regulatory and adverse market reactions which are costly for a bank, resulting in a reduction in loan issuance. The implementation of a stricter capital requirement is expected to reduce the supply of credit even further especially when banks substitute assets in a higher risk category with those in a lower risk category such as government securities in order to meet the capital requirements (Bernanke and Gertler, 1995; Bikker and Hu, 2002; Roulet, 2018). The Basel III also created a concern over the increased procyclicality of bank lending, as the risk-based capital requirements would encourage banks to maintain the same level of credit issuance only if the economic environment is favorable and the underlying risk level of the assets do not require an additional source of stable funding. For the agricultural sector, beyond the failure to secure a source of funding due to the bank's reluctance to issue credit, a decrease in bank liquidity can adversely affect farm businesses. For example, previous research has shown that decreasing credit availability can have an adverse impact on farm production value (Briggeman, Towe and Morehart, 2009). However, the direction of the effect of the new regulation on agricultural loan issuance may not be straightforward. As the risk level assigned to agricultural loans has not changed in the new regulation while other types of loans such as loans to foreign sector entities or residential mortgage loans have received higher risk weighting, agricultural loans became relatively a safer type of assets compared to higher risk assets. Also, despite the concerns addressed above, it has been argued that changes in the cost of lending due to the new regulation have been overstated in the literature, making the direction of the regulatory impact less clear.

This paper aims to examine whether or not the implementation of Basel III has resulted in significant changes in the credit availability by US banks to the agricultural sector, measured by changes in the volume of agricultural loans and changes in the banks' overall exposure to the agricultural sector. It is important to analyze whether a new regulation has had significant effects on credit issuance of banking institutions because US farmers rely heavily on both production loans and farmland real estate loans issued by banks. According to the USDA-ERS, the total agricultural production loans and farm real estate loans issued by commercial banks reached $\$ 74.9 \mathrm{bn}$ and $\$ 92.8 \mathrm{bn}$, respectively in 2018, representing 48 and 38 percent, respectively of total agricultural debt. A decrease in credit availability and increased procyclicality could negatively affect farmers especially during economic downturns when farmers need bank credit the most in order to continue their operations. An observed systematic decrease in credit availability should alarm policymakers who should consider ways to make banks more resilient while keeping them as core liquidity providers.

This study finds that US banks, including agricultural banks, did not necessarily decrease their agricultural loan volume or their overall exposure to the agricultural sector after the reinforcement of the regulation, contrary to common expectations. The findings do not conflict with the bank lending channel theory, however; the absence of a decrease in the loan volume can be attributed to the fact that many banks received an exemption from the Basel III, which is largely overlooked in literature, highlighting the importance of scrutinizing regulatory changes in greater details in policy evaluation. Significant decreases in the agricultural loan volume and in the lending growth rate are indeed observed for banks that did not receive the exemption, consistent with the bank lending channel prediction. 
Overall, this study finds that banks subject to the Basel III regulations decreased their agricultural lending relative to banks in exempt-status and that agricultural lending by all US banks did not decrease. This study contributes to the literature on agricultural economics and the literature on lending institutions in several ways. To our knowledge, this study is the first to empirically examine the impact of Basel III on agricultural loan issuance in the USA, with a specific focus on agricultural banks. Despite the importance and significance of Basel III, there are a limited number of studies conducted on the actual ramifications of the Basel III on the US agricultural sector. Additionally, this study deviates from the existing literature that has focused on simulating the bank behavior in terms of diversification or on evaluating the determinants of bank lending (Cosimano and Hakura, 2011; Roulet, 2018; Brester and Watts, 2019). This study also contributes to the lending institutions and capital requirements literature, which have garnered much interest in recent years due to new regulations and conflicting views on the ramifications of new requirements. Using OLS panel regressions and difference-in-differences approach, this study provides a causal relationship between banking regulation and bank lending growth.

\section{US implementation of the Basel III accords}

In response to the financial crisis of 2008, the Basel Committee on Banking and Supervision, a committee composed of central governors around the world, outlined the Basel III international regulatory framework for 27-member jurisdictions, which increased the regulatory capital while revising some of the definitions of capital (Getter, 2014; Roulet, 2018; BCBS, 2018). The US Congress mandated bank capital requirements from Basel III along with other regulations under the Dodd-Frank Wall Street Reform. The Board of Governors of the Federal Reserve System, the Office of the Comptroller of the Currency, and the Federal Deposit Insurance Corporation approved and published the final Basel III rule in July 2013, which became effective in 2014 and 2015. The US regulatory agencies introduced rules on risk-based capital, leverage ratio, liquidity coverage ratio, net stable funding ratio, capital conservation buffers and countercyclical capital buffers as of 2018 (BCBS, 2018). The finalized rules published in the last quarter of 2013 had a different set of rules for banks, resulting in different implications for the affected institutions (Satish et al., 2013; Getter, 2014). Different applicability of the final rule mainly depended on the size of a bank: banks with at least $\$ 250 \mathrm{bn}$ of consolidated total assets or at least $\$ 10 \mathrm{bn}$ of on-balance sheet foreign exposures were to follow the advanced approaches, with the most stringent rules and most urgent compliance, requiring advanced approaches banks to satisfy the increased capital ratios beginning on January 1, 2014. Banks that were not subject to the advanced approaches category were to follow the standard approaches rules, starting from 2015. Banks following both the advanced approaches and the standard approaches were required to increase capital ratios, establish a new minimum common equity Tier 1 capital ratio, create a capital conservation buffer of 2.5 percent, and apply a 4 percent leverage ratio requirement of Tier 1 capital to total on-balance sheet assets. The capital requirements ensure that banks secure safer and more liquid core capital, including Tier 1 capital such as common equity and preferred stock. They also modify the calculation of risk-weighted assets for banking institutions from the previous Basel regulation. Under the new risk weight scheme, more risk categories were created with a wider range of risk levels and different types of loans were assigned to new risk categories. Previously uncategorized assets such as past due exposures and non-publicly traded company equity received highrisk weights, and certain assets such as high-volatile commercial real estate loans were assigned to higher risk categories. One of the largest changes in the risk-weight calculation of the final rule is that a banking organization was required to calculate risk-weighted assets for both on-balance sheet and off-balance sheet exposures. Previous banking regulations did not consider the latter for the risk calculation. Despite these changes, the risk weighting
Basel III bank regulation on US agricultural lending

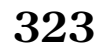


AFR

80,3

324

Table I.

Timeline of Basel III implementation in the USA given to agricultural loans did not change in the new regulation (Satish et al., 2013; US Department of Treasury, 2013; Getter, 2014; BCBS, 2018). Overall, the Basel III regulation requires banks to secure safer capital while recalculating the risk level of existing assets, effectively forcing banks to issue loans more conservatively. Table I outlines the timeline of implementation and required capital ratios that banks must satisfy with the final rule.

\section{Literature review}

The bank lending channel theory and the partial adjustment model suggest that banks react to capital regulation by altering capital and risk levels (Kashyap and Stein, 1995; Kishan and Opiela, 2000; Stolz et al., 2003; Berrospide and Edge, 2010; Brei et al., 2013). Merton (1977) developed an early theoretical model in which banks with limited liability increase shareholder value through increasing risk while decreasing capital. Koehn and Santomero (1980) show that the increase in the cost of capital from regulation reduces a bank's expected return, which results in investments in riskier assets. These early theoretical models together suggest that prudential regulation can affect the lending behavior of financial institutions (Baker and Wurgler, 2015). Following a previous theoretical framework, researchers have shown that risk-based capital requirements resulted in the 1990-1992 credit crunch, while other researchers further found that regulatory policy on banks can have a significant impact on lending growth (Berger and Udell, 1994; Peek and Rosengren, 1995; Gambacorta and Mistrulli, 2004). After the financial crisis of 2008 and the introduction of Basel III, researchers started to examine the impact of the new regulatory frameworks on the bank lending behavior. Cosimano and Hakura (2011) show that the capital requirements of Basel III increase banks' marginal cost of funding, leading to higher lending rates in select countries. Mustilli et al. (2017) conclude that upon analyzing the enforcement of the Basel III requirements that the need for compliance has been responsible for a decline in the aggregate lending by European banks. Similarly, Roulet (2018) finds that increased capital requirements have lowered the lending growth of large banks while the effects are not consistent across banks in

\begin{tabular}{|c|c|c|c|c|c|c|}
\hline & 2014 & 2015 & 2016 & 2017 & 2018 & 2019 \\
\hline \multicolumn{7}{|l|}{ Panel A: Advanced approaches banks } \\
\hline (1) Capital conservation buffer & & & 0.625 & 1.25 & 1.875 & 2.5 \\
\hline (2) Minimum Tier 1 capital ratio + (1) & 5.5 & 6.0 & 6.625 & 7.25 & 7.875 & 8.5 \\
\hline (3) Minimum total capital ratio + (1) & 8.0 & 8.0 & 8.625 & 9.25 & 9.875 & 10.5 \\
\hline (4) Countercyclical capital buffer & & & 0.625 & 1.25 & 1.875 & 2.5 \\
\hline \multicolumn{7}{|l|}{ Panel B: Standardized approaches banks } \\
\hline (1) Capital conservation buffer & & & 0.625 & 1.25 & 1.875 & 2 \\
\hline (2) Minimum Tier 1 capital ratio + (1) & & 6.0 & 6.625 & 7.25 & 7.875 & 8.5 \\
\hline (3) Minimum total capital ratio $+(1)$ & & 8.0 & 8.625 & 9.25 & 9.875 & 10.5 \\
\hline (4) Countercyclical capital buffer & & & na & na & na & na \\
\hline
\end{tabular}

Notes: The numbers in the table are the proportion of capital that is required for each category/row in a percentage term. Panel A shows the timing of regulatory requirements for advanced approaches banks. Advanced approaches banks are defined as institutions with at least $\$ 250 \mathrm{bn}$ in consolidated assets or on-balance sheet foreign exposures of at least $\$ 10 \mathrm{bn}$. Basel III requirements become effective in the calendar year 2014 for advanced approaches banks. These banks are also subject to additional countercyclical capital buffer requirements. Panel B shows the timing of regulatory requirements for standard approaches banks or standardized approaches banks. The implementation of standardized approaches starts in 2015. (1) Both advanced approaches banks and standardized approaches banks are required to increase capital conservation buffer from 0 percent of the existing rule to 2.5 percent; (2) similarly, both banks are required to increase Tier 1 capital ratio from 4 percent of the existing rule to 6 percent; (3) both banks are also required to increase total capital ratio form 6 percent of the existing rule to 10.5 percent; and (4) advanced approaches banks only. Advanced approaches banks are to increase the countercyclical capital buffer to 2.5 percent 
Europe. Gavalas (2015) finds that higher capital requirements raise the marginal cost of funding and increase lending rates in Europe. Despite these findings, the theoretical framework of the bank lending channel and the empirical findings have been questioned in the literature. It has been argued that the direction of the impact of the capital requirement is not straightforward as the enhanced capital requirements are expected to lower the risk of bank bankruptcies which offsets the increased cost of lending, resulting in insignificant changes in bank credit (Admati et al., 2013). Combined with the risk categorization of the agricultural loans discussed previously, the above argument complicates the expected direction of the agricultural lending issuance by regulated banks. Despite the significance of the regulation and its implication, studies on the impact of the Basel III on the agricultural sector have been very limited. To our knowledge, Brester and Watts (2019) is the only study to examine the implications of the Basel III in the US agricultural lending context, with results showing significant relationships between the capital reserve requirements and banks' return on equity and between diversification and reserve levels.

This study is in line with recent studies on the lending growth of banking institutions after the Basel III and contributes to the literature by focusing on US context and examining agricultural banks, which are a major source of credit for farmers. Moreover, this study shows the relationship between the regulation and lending growth by exploiting a regulatory exemption that some US banks have received, which has been overlooked in previous studies.

\section{Data}

National banks, state member banks, insured state nonmember banks and savings associations are required to file a call report every quarter. Call reports provide detailed bank-level characteristics that are used by regulatory agencies and the public to examine different aspects of a bank. For this paper, quarterly bank-level call reports for the years 2008 to 2017 are collected from the FDIC database. Fourth-quarter reports are used to match annual macroeconomic data. Farm-sector macroeconomic data are obtained from the USDA-ERS and other macroeconomic indicators are obtained from the Federal Reserve Bank of St Louis. All variables with nominal dollar value are converted to 2018 dollars. Following the definition given by the FDIC, a bank is categorized as an agricultural bank if agricultural production loans plus real estate loans secured by farmland exceed 25 percent of the bank's total loans. Following Almeida et al. (2004) and Duchin et al. (2010), observations with annual asset growth rate that are greater than 100 percent are considered to be a signal of merger activity and are dropped from the final sample. When a bank undergoes mergers and acquisitions, different assets of the target bank get consolidated in the acquiring bank's balance sheet, resulting in skewed lending patterns. The final sample comprises of 36,527 bank-year observations with 4,635 US banks, including 9,760 bank-year observations for 1,471 agricultural banks. To lower the effect of extreme outliers, observations at the 1st and 99th percentiles for all variables are dropped.

Table II provides summary statistics for the final sample. Panel A reports descriptive statistics for all US banks. The average asset size of US banks was $\$ 540.14 \mathrm{~m}$ with agricultural loans of $\$ 23.95 \mathrm{~m}$ per bank. Bank profitability or return on assets (ROA), was 0.8 percent. Bank risk, measured by total non-accrual loans divided by total gross loans, was 1.5 percent. Capital ratio (Tier 1 capital/risk-adjusted asset) and leverage ratio (Tier 1 capital/ Total asset) were 16 and 10.3 percent, respectively, suggesting that average US banks had achieved the required minimum ratios of 6 and 3 percent in the main sample period. Panel $B$ reports summary statistics for agricultural banks. These US agricultural banks were smaller than the US average: the average asset size is $\$ 174.4 \mathrm{~m}$. Despite the smaller size, these banks held significantly more agricultural loans, with an average of $\$ 46.65 \mathrm{~m}$ per bank.

Figure 1(a) and (b) present the time-trends of agricultural loans held by banks. Figure 1(a) shows the dollar volume of agricultural production loans over the years in 2018 dollar. The agricultural loans have increased from $\$ 144.71 \mathrm{bn}$ to $\$ 186.11 \mathrm{bn}$ between 2008 and 2017, with
Basel III bank regulation on US agricultural lending

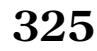




\section{AFR \\ 80,3}

326

Table II.

Descriptive statistics, 2008-2017

\begin{tabular}{llll}
\hline & Mean & SD & No. of observation \\
\hline Panel A : All US banks
\end{tabular}

Panel A: All US banks

Bank size (\$ millions)

Agricultural loan volume (\$ millions)

Ag loan/total loan

Bank ROA (net income/total assets)

Bank risk (non-accrual loan/total gross loans)

Capital ratio (Tier 1 capital/risk-adjusted assets)

Leverage ratio (Tier 1 capital/total assets)

$\begin{array}{rrr}540.137 & 1,560.284 & 36,527 \\ 23.954 & 38.391 & 36,527 \\ 0.169 & 0.191 & 36,527 \\ 0.008 & 0.008 & 36,527 \\ 0.015 & 0.018 & 36,527 \\ 0.160 & 0.062 & 36,527 \\ 0.103 & 0.026 & 36,527 \\ & & \\ 174.404 & 170.202 & 9,760 \\ 46.649 & 47.159 & 9,760 \\ 0.443 & 0.142 & 9,760 \\ 0.010 & 0.006 & 9,760 \\ 0.011 & 0.014 & 9,760 \\ 0.161 & 0.063 & 9,760 \\ 0.104 & 0.026 & 9,760\end{array}$

Panel B: US agricultural banks

Bank size (\$ millions)

Agricultural loan volume (\$ millions)

Ag Loan/total loan

Bank ROA (net income/total assets)

Bank risk (non-accrual loan/total gross loans)

Capital ratio (Tier 1 capital/risk-adjusted assets)

Leverage ratio (Tier 1 capital/total assets)

Notes: This table reports descriptive statistics for the final sample from 2008 to 2017. Panels A and B report summary statistics for all US banks and US agricultural banks, respectively. Agricultural banks are those with more than 25 percent of loans being agricultural loans
Figure 1.

A and B. Agricultural loan held by banks from 2008 to 2017
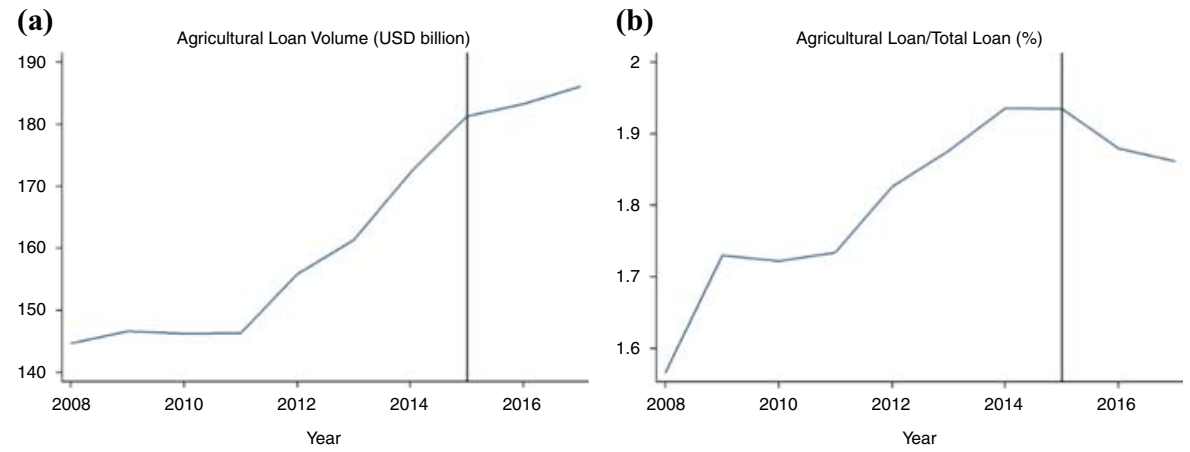

Notes: (a) Plots the total sum of agricultural production loans and real estate loans backed by farmlands, in 2018 dollars. (b) plots the agricultural loan divided by total loans and leases in percentage. The vertical line denotes the year 2015, the first year of compliance to the Basel III regulation in the United States, for banks subject to standard approaches

observable slowdown after 2015. Figure 1(b) shows the size of agricultural loans relative to the total loans over the sample period. From 2008 to 2014, the proportion of agricultural loans in the total portfolio of bank loans increased from 1.57 to 1.94 percent, a 24 percent increase. The increase continues until 2015 and then a reversal in trend is observed until the end of 2017. These figures show an early indication of a slowdown in lending growth rates of agricultural loans and banks' decreasing exposure to the agricultural sector in the post-regulation period, after 2015 when the Basel III implementation began.

\section{Empirical strategy}

The goal of this paper is to test whether there has been a decrease in the credit availability for the agricultural sector due to the reinforcement of capital requirements and risk-based 
capital from the Basel III regulation. This study analyzes the effect of the Basel III regulation on agricultural lending first through the ordinary least squares (OLS) regression as specified in Equation (1):

$$
Y_{i, t}=\alpha_{i}+\beta_{1} \text { Post Regulation }+\lambda_{1} X_{i, t-1}+\lambda_{2} Z_{t}+f_{i}+\varepsilon_{i, t},
$$

$Y_{i, t}$ represents different measures of agricultural lending behavior of bank $i$ at time $t$. To analyze the bank lending behavior in more detail, four different measures of agricultural lending behavior are used throughout the study. First, the natural logarithm of total agricultural loans is used (Agricultural Loan Volume). Second, a growth rate in the agricultural loan volume is considered. The growth rate of the loan volume is a widely used measure to examine the credit crunch in the literature (Roulet, 2018; Brei et al., 2013). The growth rate is calculated by dividing the annual change in agricultural loan amount by the previous year loan amount $(\Delta(\mathrm{Ag}$ Loan $))$. To examine how a bank changes the proportion of agricultural loans relative to the entire loan portfolio, the ratio of agricultural loans to total loans and leases is considered ( $\mathrm{Ag}$ Loan/Total Loan). The last measure used is the growth rate in the agricultural loan to total loan volume $(\Delta(\mathrm{Ag}$ Loan/Total Loan $))$.

The main variable of interest is Post Regulation, a dummy variable that takes a value of one if the observed year is in the post-Basel III regulation period. Banks that are subject to standard approaches were expected to follow the rules starting from 2015 and therefore 2015 is chosen as the effective first year of the regulation implementation. $X_{i, t-1}$ represents bank-specific characteristics for bank $i$ at time $t-1$ and $Z_{t}$ represents macroeconomic conditions that determine agricultural lending. Several papers have addressed the issue of endogeneity which occurs when the dependent variable is regressed on the bank-specific control variables at the same time $t$ (Brei et al., 2013; Roulet, 2018). To address such issue, bank characteristics are lagged one period $(t-1)$.

Previous studies indicate that bank asset size affects bank lending volume and capital structure (Berger and Udell, 1994; Roulet, 2018). To control for the size of a bank, the natural $\log$ of total assets is used (Size). Profitability is expected to affect the bank's capital structure and loan issuance, despite the mixed results (Bard et al., 2000; Stolz et al., 2003; Roulet, 2018). ROA, which is net income divided by total assets, is used to measure profitability $(R O A)$. Bank capitalization or the regulatory capital ratio is found to affect the capital structure and bank lending behavior (Brei et al., 2013; Stolz et al., 2003; Gavalas, 2015). Following the definitions given by the FDIC, the regulatory capital ratio (Capital Ratio: Tier 1 capital to risk-adjusted assets) and the leverage ratio (Leverage: Tier 1 capital to total asset) are used. A credit risk level of a bank is found to affect bank credit availability (Gavalas, 2015; Roulet, 2018), and credit risk is measured as total non-accrual loan to total gross loans (Credit Risk) in this study. As discussed above, bank characteristics control variables are lagged one period to address an endogeneity problem. To produce robust standard errors, standard errors are clustered at the bank-level.

Various macroeconomic variables and farm-sector variables are controlled in the regression as well. Previous studies have found a positive correlation between agricultural loan issuance and farm income growth (Akhavein et al., 2004). Also, agricultural land values are found to be the leading indicator for loan charge-offs and bankruptcy for agricultural lenders as changes in agricultural land values result in changes in the financial health of farmers and therefore land values affect agricultural loan issuance (Briggeman, Gunderson and Gloy, 2009). The annual growth rate in net farm income is used to measure farm income growth (Farm income) and the annual growth rate in farmland values is used to measure the change in agricultural land values (Land value). Based on previous findings, broad macroeconomic indicators that are found to significantly affect the lending behaviors of banks are also controlled. These variables
Basel III bank regulation on US agricultural lending 
AFR

80,3

328

include the GDP growth rate (GDP), the interest rate (Interest Rate), and the unemployment rate (Unemployment). Previous research has shown that bank lending practices have a cyclical relationship with macroeconomic growth (Stolz et al., 2003; Bikker and $\mathrm{Hu}, 2002$; Gavalas, 2015; Roulet, 2018). The GDP growth reflects the economic environment and it is expected to affect bank lending decisions. The annual growth rate in the real Gross Domestic Product is used. The model also controls for interest rates, as the Federal Reserve Bank alters bank behavior through a change in monetary policy or interest rates. A change in interest rates affects funding costs, and a higher interest rate reduces bank profits and thus can lower the issuance of loans (Bikker and $\mathrm{Hu}, 2002$; Brei et al., 2013; Roulet, 2018). The three-month treasury secondary market rate is used to measure the interest rate. Unemployment is a cyclical indicator that reflects the business cycle to which banks adjust their loan supply (Bikker and $\mathrm{Hu}, 2002$ ) and seasonally adjusted civilian unemployment rate is used to measure the unemployment rate. To ensure that the model does not suffer from multicollinearity across variables, a variance inflation factor test was conducted. No values with a VIF of over 10 were observed. Table II presents descriptive statistics of the variables used in the model.

\section{OLS panel regression results}

The OLS estimates for Equation (1) for the full sample are provided in Table III. It is hypothesized that the implementation of the Basel III regulation would affect the credit issuance of regulated banks according to the bank lending channel theory, and the effect is confirmed by significant coefficients on the Post Regulation in different specifications. In Column 1, the coefficient on Post Regulation on agricultural loan volume is positive and significant at the 1

\begin{tabular}{|c|c|c|c|c|}
\hline Specification & $\begin{array}{l}\text { (1) } \\
\text { Agricultural loan } \\
\text { volume }\end{array}$ & $\Delta(A g$ Loan $)$ & Ag Loan/Total Loan & $\begin{array}{c}(3) \\
\Delta(A g \text { Loan } / \text { Total } \\
\text { Loan })\end{array}$ \\
\hline Post Regulation & $0.0497 * * *(0.0082)$ & $-0.0240 * *(0.011)$ & $0.00643 * * *(0.0005)$ & $-0.0181 *(0.0095$ \\
\hline $\begin{array}{l}\text { Farm sector cont } \\
\text { Land value } \\
\text { Farm income }\end{array}$ & $\begin{array}{l}\text { rol variables } \\
\qquad-0.164^{* * *}(0.059) \\
-0.000801^{* * *}(0.0002)\end{array}$ & $\begin{array}{r}-0.254^{* * * *}(0.0666) \\
-0.0000172(0.0002)\end{array}$ & $\begin{array}{r}0.0179 * * *(0.00422) \\
-0.000124 * * *(0.0000)\end{array}$ & $\begin{array}{r}-0.129 * *(0.0617) \\
-0.0000643(0.0002)\end{array}$ \\
\hline $\begin{array}{l}\text { Macroeconomic } \\
\text { Interest Rate } \\
\text { Unemployment } \\
\text { GDP }\end{array}$ & $\begin{array}{l}\text { ontrol variables } \\
0.0120(0.0082) \\
-0.0149^{* * * *}(0.0027) \\
0.0117^{* * * *}(0.0023)\end{array}$ & $\begin{array}{r}-0.0153^{*}(0.0085) \\
-0.0123^{* * *}(0.0032) \\
-0.0161^{* * *}(0.0031)\end{array}$ & $\begin{array}{r}-0.00188 * * *(0.0006) \\
-0.00298 * * *(0.0002) \\
0.00323 * * *(0.0002)\end{array}$ & $\begin{array}{r}-0.00355(0.0075) \\
0.00241(0.0029) \\
-0.0104^{* * *}(0.0028)\end{array}$ \\
\hline $\begin{array}{l}\text { Bank characteris } \\
\text { Size } \\
\text { ROA } \\
\text { Credit Risk } \\
\text { Capital Ratio } \\
\text { Leverage } \\
\text { Constant } \\
\text { Bank-fixed } \\
\text { effects }\end{array}$ & $\begin{array}{c}0.734 * * *(0.04) \\
-0.914(0.85) \\
-0.571 * *(0.29) \\
-2.940 * * *(0.27) \\
5.182 * * *(0.58) \\
1.827 * *(0.78) \\
\text { Yes }\end{array}$ & $\begin{array}{c}-0.0879 * * *(0.024) \\
-1.256(0.82) \\
-1.600 * * *(0.23) \\
0.497 * * *(0.16) \\
-0.388(0.38) \\
1.901 * * *(0.47) \\
\text { Yes }\end{array}$ & $\begin{array}{c}-0.0130 * * *(0.002) \\
-0.118 * *(0.047) \\
0.0283(0.02) \\
-0.0263(0.026) \\
0.0411(0.044) \\
0.433 * * *(0.049) \\
\text { Yes }\end{array}$ & $\begin{array}{c}0.0237(0.02) \\
-1.445^{* *}(0.6) \\
0.0120(0.21) \\
-0.165(0.14) \\
-0.148(0.32) \\
-0.340(0.39) \\
\text { Yes }\end{array}$ \\
\hline $\begin{array}{l}R^{2} \\
\text { Observations }\end{array}$ & $\begin{array}{c}0.154 \\
36,527\end{array}$ & $\begin{array}{c}0.011 \\
36,527\end{array}$ & $\begin{array}{c}0.083 \\
36,527\end{array}$ & $\begin{array}{c}0.005 \\
36,527\end{array}$ \\
\hline
\end{tabular}

Table III.

OLS panel regression results for all US banks, 2008-2017
Notes: This table reports results from panel regressions examining agricultural lending on a bank level, from December 31, 2008, to December 31, 2017. All regressions include previously discussed control variables and bank-fixed effects. Standard errors are clustered on bank level. *******Significant at 10, 5 and 1 percent levels, respectively 
percent level. This indicates that banks in the post-regulation period have increased the agricultural loan volume. Unsurprisingly, the asset size of a bank is positively correlated with the agricultural loan volume. The negative and significant coefficient on the capital requirement ratio indicates that there is a decrease in agricultural lending as banks increase the Tier 1 capital in the previous year. A possible explanation is that banks exhaust their resources in securing safe capital such as cash and treasury bonds, therefore issuing less agricultural loans which are relatively riskier. This finding is consistent with recent studies that examine bank lending growth of European banks (Roulet, 2018). Despite the positive coefficient on Post Regulation on the agricultural loan volume, a slowdown in the lending growth rate is observed. As indicated in Column 2 and Figure 1(a), the negative and significant coefficient on Post Regulation on the growth rate in agricultural loans confirms that there has been a significant slowdown in agricultural lending after the Basel III implementation. As discussed previously, a growth rate on lending volume is a widely used measure of credit crunch and the current finding is consistent with the increased cost of lending and the subsequent behavior of a bank from the bank lending channel theory. The positive coefficient on Post Regulation on the proportion of agricultural loans to total loans in Column 3 and the negative coefficient on Post Regulation on the growth in the proportion of agricultural loans to total loans in Column 4 together present similar implications as Columns 1 and 2. The proportion of agricultural loans as a part of total loans has increased in the post-regulation period, but banks have slowed down the growth rates of the proportion of agricultural loan to total loan portfolios.

Table IV reports OLS panel regression results for agricultural banks. In Column 1, the coefficient on Post Regulation on agricultural loan volume is positive and statistically significant at 1 percent level. Column 2 shows that the growth rate in agricultural loans has slowed down. The coefficient indicates that the growth rate in agricultural loans issued by agricultural banks has declined by 3.32 percent in post regulation. The results from Columns 3 present similar findings, with agricultural loans representing a higher portion of the total loans portfolio for agricultural banks post regulation. When the growth rate of agricultural loan as a proportion of the total loan was regressed on the Post Regulation variable in Column 4, the coefficient on the Post Regulation is negative and significant. Overall, the OLS panel regressions show that banks in the post-regulation period have increased the amount of agricultural loans but with slowing down growth rates, after controlling for bank characteristics and macroeconomic factors. The results suggest that the implementation of the Basel III regulations may have slowed down the lending growth rates in the USA as predicted by the bank lending channel theory showing the impact of increased cost of lending due to the new regulation.

There are concerns regarding the validity of the above findings of increasing volume but at a slowing down growth rate as the US agricultural sector has experienced significant decreases in net farm income and net cash income after 2013. The observed negative coefficients of Post Regulation on agricultural loan growth rates in Tables III and IV, can then be a lagged reaction to the decline in the farm income. Equation (1) and the empirical estimation of OLS panel regression address this issue by incorporating the net farm income growth rate and the farm real estate growth rate as control variables, and additional tests are conducted to provide robust causal argument. Also, recent developments in the literature hint that conditioning on variables on the causal path leading from the treatment to the dependent variable, or post-treatment variables, can result in biased coefficient estimates. This is because conditioning on a post-treatment variable will change the effect from an overall average treatment effect to a direct effect of the treatment net the post-treatment variable (Acharya et al., 2016). To address the issues discussed above, three additional tests are conducted as robustness checks. First, the same panel OLS regression but with lagged farm-sector variables is examined. Second, following Acharya et al. (2016), sequential g-estimation is used to estimate the average controlled direct effect (ACDE) of the regulatory implementation on agricultural lending, after de-mediating the effect of size.
Basel III bank regulation on US agricultural lending 


\section{AFR \\ 80,3}

(1)

Agricultural Loan

Specification

(2)

Volume

Post Regulation

$0.0316 * * *(0.0054)-0.0332 * * *(0.0077)$

$\Delta($ Ag Loan $)$

(3)

(3)

$\Delta($ Ag Loan/Total

Loan)

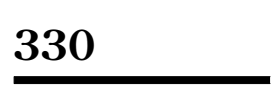

Farm sector control variables

Land value $\quad-0.251^{* * * *}(0.041) \quad-0.198^{* * * *}(0.048) \quad 0.0445^{* * * *}(0.012) \quad-0.0687 * *(0.032)$

Farm income $\quad-0.000378^{* * *}(0.0001)-0.0000994(0.0002)-0.000263^{* * * *}(0.0000) \quad 0.0000386(0.0001)$

Macroeconomic control variables

$\begin{array}{lrrrr}\text { Interest Rate } & 0.00217(0.0051) & -0.0269^{* * *}(0.0065) & -0.00479^{* * *}(0.0016) & -0.0123^{* * * *}(0.0038) \\ \text { Unemployment } & -0.0194^{* * * *}(0.0018) & -0.0124^{* * *}(0.0018) & -0.00755^{* * * *}(0.0005) & 0.000919(0.0013) \\ \text { GDP } & 0.0139^{* * *}(0.0015) & 0.00625^{* * *}(0.0015) & 0.00730^{* * *}(0.0004) & 0.00255^{* *}(0.001)\end{array}$

Bank characteristics

\begin{tabular}{|c|c|c|c|c|}
\hline Size & $0.749 * * *(0.029)$ & $-0.175 * * *(0.026)$ & $-0.0323 * * * *(0.0082)$ & $-0.00249(0.013)$ \\
\hline$R O A$ & $1.211^{* *}(0.52)$ & $0.762 *(0.42)$ & $0.0699(0.18)$ & $-0.269(0.27)$ \\
\hline Credit Risk & $-1.176^{* * * *}(0.17)$ & $-0.789 * * * *(0.16)$ & $0.0389(0.066)$ & $0.430 * * *(0.10)$ \\
\hline Capital Ratio & $-2.862 * * * *(0.25)$ & $0.921 * * *(0.14)$ & $0.0214(0.07)$ & $0.131(0.089)$ \\
\hline Leverage & $5.543 * * *(0.41)$ & $-1.877 * * *(0.27)$ & $0.146(0.13)$ & $-0.501 * * *(0.16)$ \\
\hline Constant & $3.307 * * *(0.55)$ & $3.477 * * *(0.49)$ & $1.060 * * *(0.16)$ & $0.105(0.26)$ \\
\hline $\begin{array}{l}\text { Bank-fixed } \\
\text { effects }\end{array}$ & Yes & Yes & Yes & Yes \\
\hline$R^{2}$ & 0.618 & 0.045 & 0.222 & 0.024 \\
\hline Observations & 9,760 & 9,760 & 9,760 & 9,760 \\
\hline
\end{tabular}

Table IV.

OLS panel regression results for US agricultural banks, 2008-2017

Notes: This table reports results from panel regressions examining agricultural lending on a bank level, from December 31, 2008-December 31, 2017, for agricultural banks. Following the FDIC definition, any commercial bank with agricultural production loans plus real estate loans secured by farmland exceeding 25 percent of total loans and leases is categorized as an agricultural bank. All regressions include previously discussed control variables and bank-fixed effects. Standard errors are clustered on bank level. *,**,****Significant at 10,5 and 1 percent levels, respectively

Lastly, a difference-in-differences approach is employed by examining banking institutions that have received special treatments from the finalized version of Basel III.

Table V reports OLS panel regression results with lagged agricultural sector variables to address the possibility of a lagged response by a bank to the agricultural downturn. The farm income growth rate and the real estate assets growth rate are lagged one period $(t-1)$. Even with the lagged farm-sector variables, Panel A shows that the coefficients on Post Regulation are still statistically significant for agricultural banks but the magnitude of the coefficients changes for the lagged control variables. $R^{2}$ also improves in these specifications. In Panel B, for the entire sample of US banks, the coefficients of Post Regulation on the growth rates in agricultural loan volume and in the growth rates of the agricultural loan as a proportion of the total loan volume become insignificant (Column 2 and 4). These results confirm that a decrease in the lending growth rate is significantly influenced by the financial condition of the agricultural sector and that banks may have shown lagged response to the changes in the agricultural sector financial condition. The findings still show that US agricultural banks have changed lending behaviors after the regulation, but the effect becomes insignificant especially for the entire sample.

The Basel III regulation can affect the credit issuance of targeted banks by increasing the capital requirements and recalculating and substituting assets based on risk weighting scheme, which are expected from the regulation itself, but different pathways can exist. As discussed further in the following section, a bank could receive more flexibility in regulatory enforcement if its size was small in terms of asset size, which can also alter the bank's credit issuance. Therefore, the bank size can be considered either as an alternative pathway in which 


\begin{tabular}{|c|c|c|c|c|c|}
\hline Specification & $\begin{array}{c}(1) \\
\text { Agricultural Loan } \\
\text { Volume }\end{array}$ & $\Delta(A g$ Loan $)$ & Ag Loan/Total Loan & $\begin{array}{c}(4) \\
\Delta(\text { Ag Loan/ } \\
\text { Total Loan })\end{array}$ & $\begin{array}{l}\text { Basel III bank } \\
\text { regulation on } \\
\text { US agricultural }\end{array}$ \\
\hline \multicolumn{5}{|c|}{ Panel A: US agricultural banks } & \\
\hline Post Regulation & $0.0373^{* * *}(0.0054)$ & $-0.0156 * *(0.0079)$ & $0.0133 * * *(0.0015)$ & $-0.0123 * *(0.0051)$ & \\
\hline${\text { Land } \text { Value }_{t-1}}_{1}$ & $-0.125^{* * *}(0.046)$ & $0.0439(0.059)$ & $0.0561^{* * *}(0.013)$ & $0.00459(0.042)$ & \\
\hline Farm Income $_{t-1}$ & $-0.000610 * * *(0.0001)$ & $-0.000937 * * *(0.0001)$ & $-0.0000525^{* *}(0.0000)$ & $-0.000212^{* * *}(0.0001)$ & \\
\hline Control variables & Yes & Yes & Yes & Yes & \\
\hline Bank-fixed effects & Yes & Yes & Yes & Yes & \\
\hline$R^{2}$ & 0.618 & 0.049 & 0.219 & 0.024 & \\
\hline No. of observation & 9,760 & 9,760 & 9,760 & 9,760 & \\
\hline \multicolumn{6}{|c|}{ Panel B: All US banks } \\
\hline Post Regulation & $0.0585^{* * *}(0.0076)$ & $0.00476(0.012)$ & $0.00653 * * *(0.0005)$ & $0.00299(0.011)$ & \\
\hline${\text { Land } \text { Value }_{t-1}}_{1}$ & $0.0143(0.063)$ & $0.117(0.078)$ & $0.0247 * * *(0.0045)$ & $0.141 * *(0.071)$ & \\
\hline Farm Income $_{t-1}$ & $-0.000600 * * *(0.0001)$ & $-0.00108^{* * *}(0.0002)$ & $-0.0000135 *(0.0000)$ & $-0.000433 * * *(0.0001)$ & \\
\hline Control variables & Yes & Yes & Yes & Yes & \\
\hline Bank-fixed effects & Yes & Yes & Yes & Yes & \\
\hline$R^{2}$ & 0.154 & 0.012 & 0.082 & 0.005 & \\
\hline No. of observation & 36,527 & 36,527 & 36,527 & 36,527 & \\
\hline \multicolumn{5}{|c|}{$\begin{array}{l}\text { Notes: This table reports results from panel regressions examining agricultural lending on a bank level, with lagged } \\
\text { farm sector variables, from December } 31,2008 \text {-December } 31,2017 \text {. Panels A and B report regression results for US } \\
\text { agricultural banks and all US banks, respectively. Following the FDIC definition, any commercial bank with agricultural } \\
\text { production loans plus real estate loans secured by farmland exceeding } 25 \text { percent of total loans and leases is categorized } \\
\text { as an agricultural bank. All regressions include previously discussed control variables and bank-fixed effects. Standard } \\
\text { errors are clustered on bank level. ******Significant at } 10,5 \text { and } 1 \text { percent levels, respectively }\end{array}$} & $\begin{array}{r}\text { Table V. } \\
\text { OLS panel regression } \\
\text { results with lagged } \\
\text { farm-sector control } \\
\text { variables, 2008-2017 }\end{array}$ \\
\hline
\end{tabular}

the regulation affects the bank's lending growth or as a post-treatment variable which may result in biased estimates. Since the goal of the paper is to examine the direct effect of the introduction of risk-based capital and capital requirements, a sequential g-estimation is utilized with the effect of a bank size de-mediated, following the approach in Acharya et al. (2016). The sequential g-estimation involves a two-stage regression-based procedure in which the variation in outcome (lending behavior) due to the causal effect of the mediator (bank size) is removed, and then the "de-mediated" outcome is regressed on the treatment and other control variables.

Table VI estimate the average controlled direct effect of the new regulation on agricultural lending, with different measures of agricultural lending de-mediated by the bank size. De-mediating the size does not change the estimated effect in terms of the significance level compared to the previous results from Tables III and IV. To ensure that controlling for other possible post-treatment variables does not significantly change the results, additional tests were conducted in which other possible post-treatment variables are de-mediated in unreported tables. These robustness tests yielded similar conclusions.

\section{Regulatory flexibility act and exemptions}

When the proposed Basel III rules were released in 2011 by the US regulatory agencies, the Chief Counsel for Advocacy of the Small Business Administration (CCA) filed an official letter and provided comments on the proposed rules, expressing a concern over the heavy costs of regulatory implementation for small community banks. The CCA commented that the Basel III rules were mandated for large banking institutions only and that the cost of compliance and technology implementation would be too burdensome for small banks, possibly resulting in significant bank failures. The 2013 final rule of Basel III included significant revisions from the proposed rules, reflecting the addressed concerns. Under the final rule's Regulatory Flexibility Act and regulations issued by the SBA, a bank with total assets of less than $\$ 500 \mathrm{~m}$ would be considered a small banking organization and would 


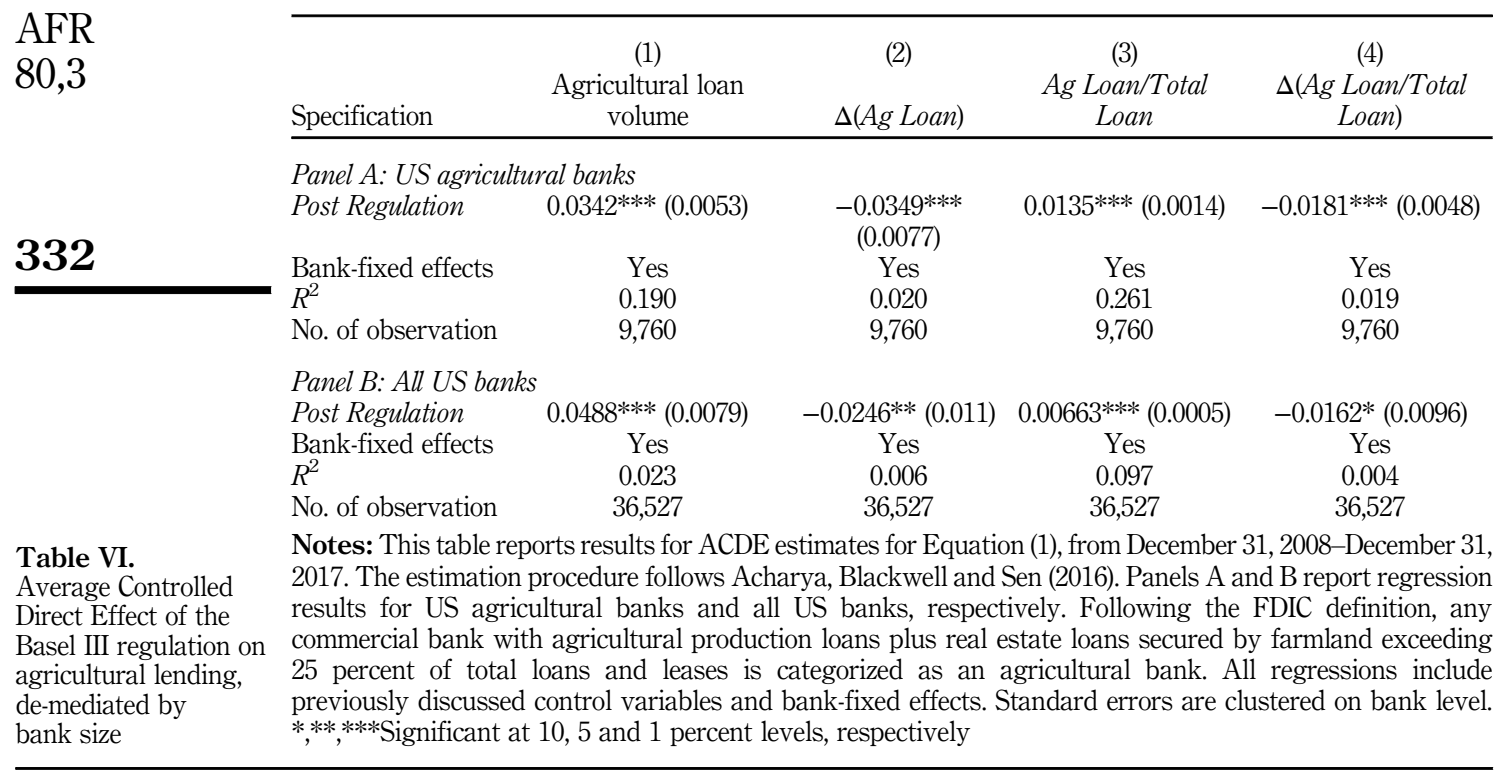

receive an exemption from regulatory capital requirements of the Basel III rule (US Department of Treasury, 2013). This special treatment for small banking institutions provides a valid setting for a difference-in-differences methodology. If the Basel III regulations affect the credit supply of the regulated banks, agricultural lending behaviors of the regulated banks (treated group) should significantly differ from the lending behaviors of banks that have received an exemption (control group) in the post regulation period. If the regulation did not have a significant impact on the regulated banks, the observed decrease in growth rates from the panel regression results should be observed for both the control group and the treated group without significant differences between them.

Figure 2(a) and (b) plot the changes in agricultural loan volume and agricultural loans as a proportion of the total loan portfolio. Each graph presents trends separately for the treated group (regulated banks) and the control group (exempted banks). Following the exemption criteria of the final rule, banks with asset size of less than $\$ 500 \mathrm{~m}$ (nominal value) are grouped into a control group (exempted) and banks with asset size greater than the threshold are grouped into a treated group (regulated). The two graphs show that both the treatment and control groups increased their agricultural loan volume during the period until 2015, with the slope for the treatment group showing some fluctuations in Figure 2(b). However, declines in agricultural loan volume and agricultural loans to total loans are observed for the treated group after 2015, while such declines are not observed for the control group. In order to evaluate whether the observed difference is statistically significant, difference-in-differences is utilized using the following equation:

$$
Y_{i, t}=\alpha_{i}+\beta_{1} \text { PostReg }+\beta_{2} \text { Regulated }+\beta_{3} \text { Post Reg } \times \text { Regulated }+\lambda_{1} X_{i, t-1}+f_{i}+\varepsilon_{i, t},
$$

where $Y_{i, t}$ represents the same dependent variables from Equation (1) that measure agricultural lending behaviors of bank $i$ at time $t$. Post Reg is an indicator variable for whether the year is after the regulation becomes effective and takes a value of one if the observed year is after 2015 and zero otherwise. Regulated takes a value of one if the bank's nominal total assets are greater than $\$ 500 \mathrm{~m}$ and zero otherwise. The model specification 
(a)

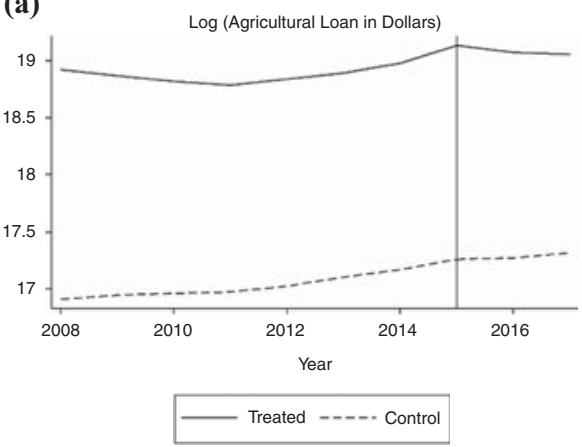

(b)

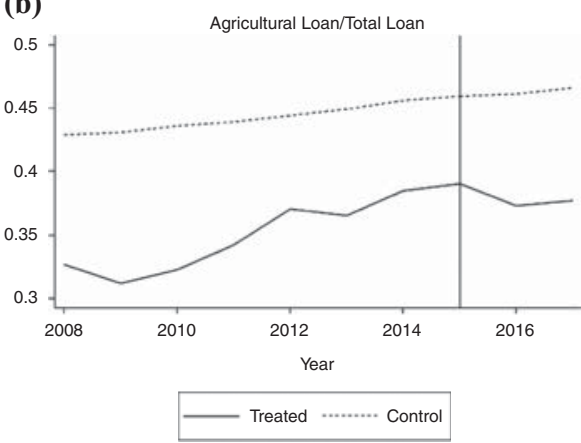

Notes: Agricultural banks are sorted into regulated group or treated group (asset size greater than $\$ 500 \mathrm{~m}$ ) and exempt group or control group (asset size greater than $\$ 500 \mathrm{~m}$ ). The figures show the log average agricultural loan volume and agricultural loan volume as a portion of total bank loan. Reference line indicates the year 2015 when the final rule of Basel III became effective

then regresses bank-level annual agricultural lending measures on the interaction term of Post Reg and Regulated to measure the effect of being regulated in the post regulation period on the agricultural loan measures.

Table VII presents the regression results for Equation (2). Results for agricultural banks are reported in Panel A. Panel A of Table VII shows a general decline in agricultural lending by agricultural banks that are subject to the new regulation regardless of the model specifications, as shown by the negative and significant coefficients on the interaction term of Post Reg and Regulated. With the agricultural lending volume as a dependent variable in Column 1 , the coefficient on the interaction term is -0.0561 and is significant at the 1 percent

\begin{tabular}{|c|c|c|c|c|}
\hline Specification & $\begin{array}{c}(1) \\
\text { Agricultural Loan } \\
\text { Volume }\end{array}$ & $\Delta(A g \operatorname{Lan})$ & $\begin{array}{c}\text { (3) } \\
\text { Ag Loan/Total } \\
\text { Loan }\end{array}$ & $\begin{array}{c}(4) \\
\Delta(A g \text { Loan } / \text { Total } \\
\text { Loan })\end{array}$ \\
\hline \multicolumn{5}{|c|}{ Panel A: US agricultural banks } \\
\hline Post Regulation & $0.106^{* * * *}(0.0062)$ & $-0.00115(0.0047)$ & $0.0303 * * *(0.0021)$ & $-0.0222 * * *(0.0029)$ \\
\hline Post Reg $\times$ Regulated & $-0.0561 * * *(0.019)$ & $-0.0344 * * *(0.013)$ & $-0.0279 * * *(0.0067)$ & $-0.0234 * *(0.0095)$ \\
\hline Control variables & Yes & Yes & Yes & Yes \\
\hline Bank-fixed effects & Yes & Yes & Yes & Yes \\
\hline$R^{2}$ & 0.602 & 0.035 & 0.137 & 0.022 \\
\hline No. of Observation & 9,760 & 9,760 & 9,760 & 9,760 \\
\hline \multicolumn{5}{|l|}{ Panel B: All US banks } \\
\hline Post Regulation & $0.134 * * *(0.011)$ & $0.00712(0.0065)$ & $0.0176^{* * * *}(0.0009)$ & $-0.0218^{* * * *}(0.0055)$ \\
\hline Post Reg $\times$ Regulated & $-0.0900 * * *(0.027)$ & $0.0103(0.015)$ & $-0.0155 * * *(0.0013)$ & $-0.0110(0.013)$ \\
\hline Control variables & Yes & Yes & Yes & Yes \\
\hline Bank-fixed effects & Yes & Yes & Yes & Yes \\
\hline$R^{2}$ & 0.152 & 0.007 & 0.054 & 0.002 \\
\hline No. of observation & 36,527 & 36,527 & 36,527 & 36,527 \\
\hline
\end{tabular}

Notes: This table reports results from panel regressions for Equation (2), from December 31, 2008, to December 31, 2017. Panels A and B report regression results for US agricultural banks and all US banks, respectively. Following the FDIC definition, any commercial bank with agricultural production loans plus real estate loans secured by farmland exceeding 25 percent of total loans and leases is categorized as an agricultural bank. All regressions include previously discussed control variables and bank-fixed effects. Standard errors are clustered on bank level. *******:Significant at 10, 5 and 1 percent levels, respectively

Basel III bank regulation on US agricultural lending 333

Figure 2. Agricultural lending volume, 2008-2017

- 
AFR

80,3

334

Table VIII.

Differences-indifferences results with different asset size cutoff of $\$ 350 \mathrm{~m}$, 2008-2017 level, indicating that agricultural banks subject to the regulation have decreased the volume of agricultural loans by 5.61 percent during the post regulation period. In Column 2 , when the dependent variable is the lending growth rate, the interaction term is again negative and significant at the 1 percent level, indicating that the lending growth rates have significantly decreased for the regulated agricultural banks relative to the exempted agricultural banks in the post-regulation period. Column 3 and 4 further show that the agricultural loans as a percentage of the total loan portfolio and the growth rate as a part of loan portfolio decreased for the regulated agricultural banks after 2015. Panel B of Table VII presents results for the entire sample of US banks. Panel B presents similar findings to those in Panel A, indicating all US banks, not only agricultural banks, subject to new regulation have decreased the agricultural loan volume in the post regulation period. Column 2 shows that the regulation was not associated with a decrease in the agricultural loan growth rates, as indicated by the statistically insignificant coefficient on the interaction term. Columns 3 and 4 report similar findings: the proportion of agricultural loans in the total loan portfolio itself decreased but its growth rate did not significantly change for the regulated banks in the post regulation period for the entire sample. To ensure that the finding is not simply driven by a difference in size, additional robustness tests with a different size cutoff of $\$ 350 \mathrm{~m}$ were conducted. In the robustness test, banks with an asset size between $\$ 350 \mathrm{~m}$ and $\$ 500 \mathrm{~m}$ are categorized as a treated group and banks with an asset size between $\$ 200 \mathrm{~m}$ and $\$ 350 \mathrm{~m}$ are categorized as a control group. As reported in Panel A of Table VIII, coefficients on the interaction term of Post Regulation and Regulated are insignificant across all specifications for agricultural banks, confirming the above finding that the difference in bank lending behavior is driven by the regulation, not simply by the size differences. Panel B of Table VIII provides similar findings with the only exception of the growth rate of the agricultural loan volume as a proportion of the total loans.

Overall, the results show that the Basel III regulation has had significant impacts on regulated US agricultural banks. Traditionally, these agricultural banks have been the major source of credit for US farmers. Consistent with the bank channel theory in which the regulation affects the cost of lending of the lending institutions, this paper finds that banks

\begin{tabular}{|c|c|c|c|c|}
\hline Specification & $\begin{array}{c}(1) \\
\text { Agricultural Loan } \\
\text { Volume }\end{array}$ & $\Delta(A g$ Loan $)$ & $\begin{array}{c}(3) \\
\text { Ag Loan/Total } \\
\text { Loan }\end{array}$ & $\begin{array}{c}(4) \\
\Delta(\text { Ag Loan } / \text { Total } \\
\text { Loan })\end{array}$ \\
\hline \multicolumn{5}{|c|}{ Panel A: US agricultural banks } \\
\hline Post Reg $\times$ Regulated & $-0.0116(0.0167)$ & $-0.00773(0.0173)$ & $-0.00365(0.00620)$ & $0.00960(0.0130)$ \\
\hline Control variables & Yes & Yes & Yes & Yes \\
\hline Bank-fixed effects & Yes & Yes & Yes & Yes \\
\hline No. of observation & 0.609 & 0.094 & 0.155 & 0.026 \\
\hline$R^{2}$ & 2,006 & 2,006 & 2,006 & 2,006 \\
\hline \multicolumn{5}{|l|}{ Panel B: All US banks } \\
\hline Post Reg $\times$ Regulated & $0.0238(0.0339)$ & $0.0386(0.0251)$ & $-0.000637(0.00194)$ & $0.0479 * *(0.0217)$ \\
\hline Control variables & Yes & Yes & Yes & Yes \\
\hline Bank-fixed effects & Yes & Yes & Yes & Yes \\
\hline No. of observation & 0.098 & 0.012 & 0.062 & 0.002 \\
\hline$R^{2}$ & 10,047 & 10,047 & 10,047 & 10,047 \\
\hline
\end{tabular}

Notes: This table reports results from panel regressions for Equation (2), from December 31, 2008-December 31, 2017. Panels A and B report regression results for US agricultural banks and all US banks, respectively. Following the FDIC definition, any commercial bank with agricultural production loans plus real estate loans secured by farmland exceeding 25 percent of total loans and leases is categorized as an agricultural bank. All regressions include previously discussed control variables and bank-fixed effects. Standard errors are clustered on bank level. ***,***Significant at 10, 5 and 1 percent levels, respectively 
that had a significant exposure to the agricultural sector indeed decreased their volume of agricultural loans and their exposure to the agricultural sector once they became subject to the new Basel III regulations. Even though this particular finding might be concerning, the results from the overall US sample suggest that agricultural loan volume has not declined post regulation. This result can be attributed to the fact that many agricultural banks are relatively small in comparison to the average US bank in terms of asset size, and as such they received a special exemption from the regulatory agencies.

\section{Conclusions and implications}

This study examines whether the implementation of the Basel III regulation has resulted in changes in agricultural loan issuance by US banks as predicted by the lending channel theory. The direction of the change was not expected to be straightforward as agricultural loans received the same risk rating under the new regulation while other types of loans were categorized into different risk levels or higher risk levels. The results from the OLS regression and other robustness tests show that US banks did not decrease their agricultural lending in terms of volume after the regulation. Exploiting the regulatory exemption that banks received, this study finds that agricultural banks that are subject to the regulation have indeed decreased their agricultural loans relative to agricultural banks that received regulatory exemptions in the post-regulation period. Even though the decrease in agricultural lending and negative growth rates from agricultural banks might be compatible with the predictions from lending channel theory and other empirical findings, the mixed findings for the average US bank present interesting implications regarding the new regulation. Brester and Watts (2019) predicted that the reduction in capital reserve requirements caused by the loan diversification would encourage non-traditional agricultural lenders to substitute their existing loans with agricultural loans as the diversification will lower the cost associated with calculating the risk levels of the loan portfolio. The finding of increases in the agricultural lending volume can be attributed to this explanation and can allow opportunities for future research.

The observed decrease in credit availability due to regulation should alarm policymakers and practitioners and encourage them to consider ways to make banks more resilient while still keeping them as major liquidity providers for farmers. The issue of credit availability for farmers gains more relevance and calls for a detailed policy review especially during economic downturns when farmers need bank credit the most in order to continue farming their operations, as they cannot secure enough capital due to a decrease in farm income. With the recent economic downturn in the agricultural sector, farmers may further seek loans from traditional agricultural lenders which are now found to decrease lending to the agricultural sector after the new regulation. Policymakers may find it necessary to review whether farmers can seek alternate ways to obtain credit other than from regulated banks. Future research should be conducted on whether this decrease in credit availability has had adverse impacts on farm operations, loan delinquency rates, and loan provisions. Also, further examinations of the heterogenous bank characteristics and their relationship with the Basel III regulation and changes in their behavior will give insights on the ramification of the new regulation on the economy.

\section{References}

Acharya, A., Blackwell, M. and Sen, M. (2016), "Explaining causal findings without bias: detecting and assessing direct effects”, American Political Science Review, Vol. 110 No. 3, pp. 512-529.

Admati, A.R., DeMarzo, P.M., Hellwig, M.F. and Pfleiderer, P.C. (2013), "Fallacies, irrelevant facts, and myths in the discussion of capital regulation: why bank equity is not socially expensive", working paper, Stanford University.
Basel III bank regulation on US agricultural lending 
Akhavein, J., Goldberg, L.G. and White, L.J. (2004), "Small banks, small business, and relationships: an empirical study of lending to small farms", Journal of Financial Services Research, Vol. 26 No. 3, pp. 245-261.

Almeida, H., Campello, M. and Weisbach, M.S. (2004), "The cash flow sensitivity of cash", The Journal of Finance, Vol. 59 No. 4, pp. 1777-1804.

Baker, M. and Wurgler, J. (2015), "Do strict capital requirements raise the cost of capital? Bank regulation, capital structure, and the low-risk anomaly", The American Economic Review, Vol. 105 No. 5, pp. 315-320.

Bard, S.K., Barry, P.J. and Ellinger, P.N. (2000), "Effects of commercial bank structure and other characteristics on agricultural lending", Agricultural Finance Review, Vol. 60 No. 1, pp. 17-31.

Basel Committee on Banking Supervision (Ed.) (2018), Fourteenth Progress Report on Adoption of the Basel Regulatory Framework April, Bank for International Settlements, Basel.

Berger, A.N. and Udell, G.F. (1994), "Did risk-based capital allocate bank credit and cause a "credit crunch' in the United States?", Journal of Money, Credit and Banking, Vol. 26 No. 3, pp. 585-628.

Bernanke, B.S. and Gertler, M. (1995), "Inside the black box: the credit channel of monetary policy transmission”, Journal of Economic Perspectives, Vol. 9 No. 4, pp. 27-48.

Berrospide, J.M. and Edge, R.M. (2010), "The effects of bank capital on lending: what do we know, and what does it mean?”, International Journal of Central Banking, Vol. 6, pp. 5-54.

Bikker, J.A. and Hu, H. (2002), "Cyclical patterns in profits, provisioning and lending of banks and procyclicality of the new Basel capital requirements", PSL Quarterly Review, Vol. 55 No. 221, pp. 143-175.

Brei, M., Gambacorta, L. and von Peter, G. (2013), "Rescue packages and bank lending", Journal of Banking \& Finance, Vol. 37 No. 2, pp. 490-505.

Brester, G.W. and Watts, M.J. (2019), "The Basel accords, capital reserves, and agricultural lending”, Agricultural Finance Review, Vol. 79 No. 1, pp. 27-47.

Briggeman, B.C., Gunderson, M.A. and Gloy, B.A. (2009), "The financial health of agricultural lenders", American Journal of Agricultural Economics, Vol. 91 No. 5, pp. 1406-1413.

Briggeman, B.C., Towe, C.A. and Morehart, M.J. (2009), "Credit constraints: their existence, determinants, and implications for US farm and nonfarm sole proprietorships", American Journal of Agricultural Economics, Vol. 91 No. 1, pp. 275-289.

Cosimano, T.F. and Hakura, D.S. (2011), "Bank behavior in response to Basel III: a cross-country analysis".

Duchin, R., Ozbas, O. and Sensoy, B.A. (2010), "Costly external finance, corporate investment, and the subprime mortgage credit crisis", Journal of Financial Economics, Vol. 97 No. 3, pp. 418-435.

Gambacorta, L. and Mistrulli, P.E. (2004), "Does bank capital affect lending behavior?", Journal of Financial Intermediation, Vol. 13 No. 4, pp. 436-457.

Gavalas, D. (2015), "How do banks perform under Basel III? Tracing lending rates and loan quantity", Journal of Economics and Business, Vol. 81, pp. 21-37.

Getter, D.E. (2014), "US Implementation of the Basel Capital Regulatory Framework”, Congressional Research Service April, Washington, DC.

Kashyap, A.K. and Stein, J.C. (1995), "The impact of monetary policy on bank balance sheets", Carnegie-Rochester Conference Series on Public Policy, Vol. 42, pp. 151-195.

Kishan, R.P. and Opiela, T.P. (2000), "Bank size, bank capital, and the bank lending channel”, Journal of Money, Credit and Banking, Vol. 32 No. 1, pp. 121-141.

Koehn, M. and Santomero, A.M. (1980), "Regulation of bank capital and portfolio risk", The Journal of Finance, Vol. 35 No. 5, pp. 1235-1244.

Merton, R.C. (1977), "An analytic derivation of the cost of deposit insurance and loan guarantees an application of modern option pricing theory", Journal of Banking \& Finance, Vol. 1 No. 1, pp. 3-11.

Mustilli, M., Campanella, F. and D’Angelo, E. (2017), "Basel III and credit crunch: an empirical test with focus on Europe", Journal of Applied Finance and Banking, Vol. 7 No. 3, pp. 47-56. 
Peek, J. and Rosengren, E. (1995), "Bank regulation and the credit crunch", Journal of Banking \& Finance, Vol. 19 Nos 3-4, pp. 679-692.

Repullo, R. and Saurina, J. (2011), The Countercyclical Capital Buffer of Basel III: A Critical Assessment, CEMFI, Madrid.

Roulet, C. (2018), "Basel III: effects of capital and liquidity regulations on European bank lending", Journal of Economics and Business, Vol. 95, pp. 26-46.

Satish, K., Lee, P.L., Lyons, G.J., Patton, P., Proctor, S. and Luigs, D.A. (2013), “The final US Basel III lending capital framework I practical law", available at: https://content.next.westlaw.com/Document/ Ieaf716a0641111e38578f7ccc38dcbee/View/FullText.html?transitionType=Default\&contex tData $=$ (sc.Default) (accessed May 8, 2019).

Stolz, S., Heid, F. and Porath, D. (2003), "Does capital regulation matter for bank behavior? Evidence for German savings banks", Discussion Paper Series 2, Deutsche Bundesbank, March.

US Department of the Treasury (2013), "12 CFR Parts 3, 5, 6, 165, and 167, "Regulatory capital rules: regulatory capital, implementation of Basel III, capital adequacy, transition provisions, prompt corrective action, standardized approach for risk-weighted assets, market discipline and disclosure requirements, advanced approaches risk-based capital rule, and market risk capital rule; final rule", Federal Register, Vol. 78 No. 198, pp. 62017-62291.

\section{Further reading}

Basel Committee on Banking Supervision (Ed.) (2014), "Regulatory Consistency Assessment Programme (RCAP): assessment of Basel III regulations - United States of America”, Bank for International Settlements, Basel, December.

Borio, C. and Zhu, H. (2012), "Capital regulation, risk-taking and monetary policy: a missing link in the transmission mechanism?”, Journal of Financial Stability, Vol. 8 No. 4, pp. 236-251.

Nam, S., Ellinger, P.N. and Katchova, A.L. (2007), "The changing structure of commercial banks lending to agriculture", p. 34.

\section{Corresponding author}

Ani L. Katchova can be contacted at: katchova.1@osu.edu

For instructions on how to order reprints of this article, please visit our website: 